\title{
Augmentation of germination in Sapindus mukorossi due to acid scarification in Jhanjhatpur nursery
}

\author{
H. B. Thapa ${ }^{1}$ and S. K. Gautam ${ }^{2}$
}

\begin{abstract}
The study on 'effects of pre-sowing treatments on germination of Sapindus mukorossi Gaertn,' was carried out in Jhanjhatpur nursery, Kailali district in April 2004. About 15months old healthy seeds were treated in one of thirty ways before sowing and sown from 1 to 7 April 2004 in drills in a nursery bed at a spacing of $5 \mathrm{~cm} \times 10 \mathrm{~cm}$. The analysis revealed that thirty pre-treatments significantly differed in germination in 1-month (4-weeks) and 2-months (9-weeks) but these pre-treatments did not vary in 3-months (13-weeks). In 4-weeks, the pre-treatment, 90-minutes in concentrated hydrochloric acid significantly differed with twenty-five pre-treatments except the four pre-treatments of 15, 45, 60 and 75 minutes in concentrated acid. The highest germination (90\%) was found in the pretreatment, 90-minutes in acid, which was followed by the germination (63\%) in the pretreatment, 75-minutes in concentrated acid in 3-weeks. The highest non-germinated good seeds were in pre-treatment, $30 \%$ in 96 hours in cold water, followed by the pre-treatment, $27 \%$ in 5-minutes in boiled water and 72 -hours in cold water. The highest non-germinated rotten seeds were in the pre-treatments, 3-minutes in boiled water and 72-hours in cold water and 10 minutes in acid, followed by the five pre-treatments, 3-minutes in boiled water and 120 hours in cold water, 5-minutes in boiled water then 24 and 72 hours in cold water, 5-minutes and 60-minutes in concentrated acid. The two pre-treatments, 75 and 90 minutes in concentrated acid can be used to get quicker and higher germination. The four pre-treatments, 3 minutes in boiled water and 48 hours in cold water, 5-minutes in boiled water and 120 hours in cold water, 144 hours in cold water and 120 hours in cow dung slurry are suggested as an alternative to acid treatments, if acid is not readily available in the market and there is a problem of handling the acid.
\end{abstract}

Key words: Sapindus mukorossi, germination, acid, pre-treatment

$S$ apindus mukorossi (rittha) Gaertn. is considered as an important NTFPs found in western Nepal. It is large sized tree and primarily grows from $1000 \mathrm{~m}$ to $1400 \mathrm{~m}$ in Nepal. It prefers open and sunny places. In Rapti area, it is found in Salyan, Rukum, Rolpa and Pyuthan districts (EFEA 1998). It has been widely planted in Nepal and many countries of tropical Asia (Jackson 1994).

Its importance mainly lies with the sale of fruits. Its fruits are mainly sold in local markets. A number of farmers have benefited by selling and marketing the fruits from their planted trees. As the domestication and cultivation is being started the demand of quality seedling in proper planting time is very high. Low, delayed and uneven germination have created problem in raising seedlings in nursery. The evidence of delayed and uneven germination was observed in Jhanjhatpur nursery, Kailali in 2001, where seeds were found to germinate even after ten months. Delayed and uneven germination of seeds is very common in private, community or governmental nurseries in Nepal. As a result, nursery naikes have got problem to produce the seedlings in a targeted quantity within the stipulated time. Consequently, it is difficult for nursery naikes to meet the annual plan of seedlings production.

According to some researchers, the improvement in germination of rittha seeds can be achieved by using pre-sowing treatments, cow dung slurry and acid (Braham, Sree and Saxena 1996; Sheikh 1979); hot water treatment (Jackson, 1994 and Campbell 1983). Suitable pre-sowing treatments for even quicker and higher germination have not been identified yet. As a result there is normal practice of sowing seeds without pre-treatment in many nurseries in Nepal. Thus, identification of suitable pre-sowing treatment

\footnotetext{
${ }^{1}$ Research Officer DFRS (E-mail: thapahb@yahoo.com)

${ }^{2}$ Asst. Research Officer DFRS (E-mail: Shreekgautam@yahoo.com)
} 
is necessary so that shortage of quality seedlings during plantation is greatly reduced. So, a study on 'effect of some pre-sowing treatments on the seed germination' was carried out in Jhanjhatpur nursery located in far western Nepal in order to test, identify, and recommend few suitable pre-sowing treatments of Sapindus mukorossii (rittha).

\section{Materials and methods}

The experiment was carried out in Jhanjhatpur nursery in Kailali district in April 2004. The nursery is situated in the terai region (flat land). It has subtropical climate and altitude is about $200 \mathrm{~m}$. According to the climatic data (April-July 2004) of Dhangadhi located at about $14 \mathrm{~km}$ south of the nursery, the mean maximum and minimum temperatures were $35^{\circ} \mathrm{C}\left(32.7^{\circ} \mathrm{C}\right.$ in July to $36.6^{\circ} \mathrm{C}$ in May) and $22.8^{\circ} \mathrm{C}\left(19.5^{\circ} \mathrm{C}\right.$ in April to $24.8^{\circ} \mathrm{C}$ in July $)$ respectively. The mean daily temperature was $28.9^{\circ}$ $\mathrm{C}$ during this period. The mean relative humidity was $76.6 \%$ (65\% in April to $91.7 \%$ in July) at 08.45 hours and $59.3 \%$ (39.9\% in April to $79.7 \%$ in July) at $17: 45$ hours respectively. The mean rainfall of four months was $210.4 \mathrm{~mm}$ ( $45.6-514.6 \mathrm{~mm})$ and the total rainfall was $841.4 \mathrm{~mm}$. The climatic data sheets were taken from Department of Hydrology and Meteorology, Babar Mahal, Kathmandu.

The seeds were collected in January 2003 in Surkhet district (FRD seed lot number: 2125). About 15months old healthy seeds were selected manually and they were treated in one of thirty ways before sowing (see annex 1). The seeds were sown from 1 to 7 April 2004 in drills in a nursery bed at a spacing of $5 \mathrm{~cm} \mathrm{x}$ $10 \mathrm{~cm}$ (seed to seed $5 \mathrm{~cm}$ and one line to another 10 $\mathrm{cm})$. The bed consisted of three parts soil and one part sand. Thirty seeds were sown in three replicates (ten seeds per replicate). Germination record was done in an interval of seven days and continued up to 3.5 months i. e. 105 days. In June 21, 2004, nongerminated seeds were dug out and categorised into two classes: non-germinated good and rotten seeds. Watering, and weeding were done as required.

Mean germination figures were calculated up to 3.5 months. The mean germination figures of 1,2 and 3-months (28, 63 and 91 days) were transformed into arcsine figures and two-way anova was done at 5\% level to detect the differences between germination figures of different pre-sowing treatments. A multiple comparison was done using Tukey's test.

\section{Results and Discussions}

The analysis revealed that thirty pre-treatments significantly differed in germination in 1-month (4weeks) and 2-months (9-weeks) but these pretreatments did not vary in 3-months (13-weeks). In 4-weeks, the pre-treatment, 75-minutes in acid significantly differed with the eighteen pre-treatments, 3 -minutes in boiled water and 24, 72 and 96 hours in cold water; 5-minutes in boiled water and 24, 72 and 96 hours in cold water; 24, 48, 72, 96, 120, and 144 hours in cold water; 72, 120, 144 and 168 hours in cow dung slurry; 3 and 5 minutes in concentrated hydrochloric acid but not significantly different with eleven pre-treatments, 3 -minutes in boiled water followed by 48 and 120 hours in cold water; 5 minutes in boiled water and 48 and 120 hours in cold water; 120 hours in cow dung slurry; 10, 15, 30, 45 and 60 minutes in acid. The pre-treatment, 90-minutes in concentrated acid, was significantly different with twenty-five pre-treatments except the four pretreatments, 5, 45, 60 and 75 minutes in concentrated hydrochloric acid. The pre-treatment, 90-minutes in concentrated acid was found superior to all of the pre-treatments. Similarly, pre-treatments A to Z (boiled and cold water, cold water only, cow dung slurry, 3, 5, 10, 15, and 30 minutes in concentrated acid) did not vary significantly in germination. Pretreatments, 45-minutes and 60-minutes in concentrated acid varied significantly with pretreatment, 5 minutes in boiled water and 24 hours in cold water, and 60-minutes in acid) with the pretreatment, 24-hours in cold water and 168 hours in cow dung slurry) (annex 1).

In 2-months (9-weeks), the two pre-treatments, 75 and 90 -minutes in concentrated acid varied significantly with two pre-treatments, 48-hours in cold water and 10-minutes in acid. Twenty-eight pretreatments $\mathrm{A}$ to $\mathrm{AB}$ (boiled and cold water, cold water only, cow dung slurry, 3, 5, 10, 15, 30, 45 and 60minutes in concentrated acid) were found similar in germination. Among the nine acid pre-treatments, eight pre-treatments were significantly different in germination with 10-minutes in concentrated acid (annex 1). In 3-months (13-weeks), all the thirty pretreatments were similar in germination (annex 1).

Seeds did not germinate up to 2 weeks in all of the thirty pre-treatments. The highest germination $(90 \%)$ was found in the pre-treatment, 90-minutes in concentrated hydrochloric acid, which was followed by the germination $(63 \%)$ in the pre-treatment, 75 - 
minutes in acid in 3-weeks. It clearly indicated that these two pre-treatments were certainly better in germination than other pre-treatments in a shorter period. Seeds germinated in twenty-five pretreatments in this period (annex 2) whereas all the pre-treatments germinated in 4-weeks. Although, initiation of germination is not a key factor to select the pre-treatments, but the key factor is to get higher germination in a shorter period. As the most pretreatments had poor germination up to 4 -weeks (annex 2). Four acid pre-treatments, 45, 60, 75 and 90 minutes in acid, had germination range from 73 $97 \%$ in 5-weeks, which are highly promising germination results. Excluding acid pre-treatments, $60 \%$ or higher germination was recorded in four pretreatments, 3 -minutes in boiled water and 48 hours in cold water, 5 -minutes in boiled water and 120 hours in cold water, 144 hours in cold water) and 120 hours in cow dung slurry in 7-weeks. These four pretreatments can be used as an alternative to acid pretreatments in those nurseries, where acid is scarce and problem in using acid properly. In 3-months (13 weeks), twenty-three pre-treatments had $70 \%$ or higher germination. Seeds germinated well in that period except seven pre-treatments, 3 and 5-minutes in boiled water followed by 72 and 96 hours in cold water; 24, 96, and 120 hours in cold water and 10 minutes in concentrated acid (annex 2).

The highest non-germinated good seeds were in pretreatments, 96 hours in cold water $(30 \%)$, followed by the pre-treatment, 5 -minutes in boiled water and 72 -hours in cold water (27\%). Good seeds were not recorded in three pre-treatments, 45, 60 and 90 minutes in acid. The other seven pre-treatments, which had 20 or higher than $20 \%$ non- germinated good seeds, were 3-minutes in boiled water and 24 hours in cold water; 5 -minutes in boiled water and 72-hours in cold water; 24, 72, 96, 120 hours in cold water respectively), and 144 hours in cow dung slurry (annex 3).

The highest non-germinated rotten seeds were recorded in two pre-treatments, 3-minutes in boiled water and 72-hours in cold water and 10 minutes in acid, followed by the five pre-treatments, 3-minutes in boiled water and 120 hours in cold water; 5 -minutes in boiled water, then 24 and 72 hours in cold water; 5 and 60 minutes in acid. In general, the percentage of non-germinated rotten seeds was $10 \%$ or lower than it. None seeds were found rotten in six pretreatments, 96 and 144 hours in cold water; 144 and 168 hours in cow dung slurry; (75 and 90 minutes in acid and less than 5\% in eight pre-treatments, 3minutes in boiled water, then 24 and 48 -hours in cold water; 5-minutes in boiled water and 96-hours in cold water; 24, 48 and 72hours in cold water; 120 hours in cow dung slurry and 15-minutes in acid (annex 3).

Either concentrated hydrochloric acid or cow dung slurry stimulated germination in S. mukorossi (77-82\%) in 21 days (Braham, Sree and Saxena 1996). These promising germination results in acid scarification are similar to this study. Germination ranged from 0 for 96 hours to $13 \%$ in 120 hours in cow dung slurry in this study. Similar poor germination figures were recorded in one study done by Thapa (2001). These results are very poor as compared to the germination figures stated by these researchers. The reason for poor germination in these studies is not clear, further verification is needed using fresh and old seeds for comparison. A lower germination (7-11\%) was found in hot water treatment, which is similar to this study (0 to $17 \%$ ) within that period. They recommended that cow dung treatment was found as an effective and cheap treatment. Generally, their recommendations for pre-treatment, cow dung slurry, cannot be implied in Nepal based on this study. The seeds soaking in acid for 20-minutes significantly improved the germination (Sheikh 1979) and he found similar results in boiling water followed by cold water treatment The findings of the present study correspond to the results of Sheikh (1979) in case of acid scarification. Similarly, Campbell (1983) reported the improvement in germination with the pre-sowing treatment of immersing the seeds in hot water and leaving for some days. But it is unclear about the temperature of hot water, number of days required for soaking the seeds and germination period. This pre-treatment also needs to verify, particularly in different temperatures of hot water and duration of soaking. Although, Jackson (1994) stated that the seeds should be put on hot water and left it for seven days. Again the same question arises on the temperature and duration of soaking in hot water.

In general, it was found that seeds germinated faster in acid pre-treatments than other pre-treatments (annex 1) indicating the positive response of acid to hasten the germination. Again, germination increased with the increase in duration of soaking in acid, as there was $90 \%$ germination in 90-minutes soaking in acid in 3-weeks. Soaking the seeds only in cold water for different periods $(24,48,72,96$, and 120 
144 hours) did not improve the germination, as the germination ranged from 30 to $43 \%$ in 7 -weeks. Similar poor germination results were found in another study in that nursery (Thapa 2001). Soaking in cold-water for 120 hours or less is insufficient for the improvement of germination for this species. The germination was recorded as $63 \%$ in the pretreatment, 144 hours in cold water within that period (annex 2). It indicates the possibility of improvement in germination due to soaking seeds in cold water for longer periods (144 hours or more), although its confirmation is needed through study.

\section{Conclusion and recommendations}

Generally, acid scarification is the most effective pretreatment for quicker and higher germination of this species. The two acid treatments (75 and 90 minutes in concentrated hydrochloric acid) can be used to have higher and quicker germination. In case of unavailability of acid and problem in using acid properly, the four pre-treatments, 3 minutes in boiled water and 48 hours in cold water, 5 -minutes in boiled water and 120 hours in cold water, 144 hours in cold water and 120 hours in cow dung slurry are suggested as an alternative to acid treatments.

The following recommendations are made, which are as follows:

- A study is needed on duration of soaking in concentrated acid for $60,75,90$ minutes or more and effects on germination due to diluted acid, soaking in cold water for 144 hours (6 days) or more, duration of seeds in boiled water for more than 5 minutes, followed by different duration of soaking in cold water and duration of soaking in cow dung slurry for 120 hours or more.

- Demonstration to nursery naikes on proper use of concentrated acid as a pre-treatment.

\section{Acknowledgement}

We acknowledge Dhan B. Thing for his contribution in establishment of the experiment, recording, supervision, and data collection.

\section{References}

Brahmam, M; Sree, A. and Saxena C. 1996. Effect of pre-sowing treatments on the seed germination of Sapindus mukorossi Gaertn. and Sapindus trifolintus L. (Sapindaceae). Advances in Plant Sciences 9(1): $137-$ 142.

Campbell, M. W. 1983 Plant Propagation for Reforestation in Nepal. Revised edition. Australian National University. Nepal-Australia Forestry Project. Technical Note 1/83.

Department of Hydrology and Meteorology, 2004. Climatic Data Sheets of Dhangadhi. April to July, 2004.

EFEA 1998 Ritha (in Nepali). Ban Paidawar Mala-8. Environmental Forestry Enterprise Activity. Forestry Enterprise - B. S. P. / New Era, Nepalgunj, Banke.

Jackson, J. K. 1994. Manual of Afforestation in Nepal. Volume 2. Second edition. Forest Research and Survey Center, Babar Mahal, Kathmandu.

Sheikh, M. I. 1979. Tree seeds respond to acid scarification. Pakistan Journal of Forestry 29(4): 253254.

Thapa, H. B. 2001. Effect of some pre-sowing treatments on the seed germination of Sapindus mukorossi Gaertn. Banko Janakari 12(2): 65-68 
Annex 1: Arcsin germination figures and results of Tukey's test

\begin{tabular}{|c|c|c|c|c|}
\hline \multirow[b]{2}{*}{ Treatment type } & \multirow{2}{*}{$\begin{array}{l}\text { Treatment } \\
\text { code }\end{array}$} & \multicolumn{3}{|c|}{ Arcsine germination figures } \\
\hline & & $\begin{array}{c}\text { 1-month } \\
\text { (28 days)* }\end{array}$ & $\begin{array}{l}\text { 2-months } \\
\text { (63 days)* }\end{array}$ & $\begin{array}{l}\text { 3-months } \\
\text { (91 days)* }\end{array}$ \\
\hline 3 -minutes in boiled water and 24 hours in cold water & A & 21.9abc & $53.1 \mathrm{ab}$ & $66.1 \mathrm{a}$ \\
\hline 3-minutes in boiled water and 48 hours in cold water & B & 26.1 abcd & $50.9 \mathrm{ab}$ & $61.7 \mathrm{a}$ \\
\hline 3-minutes in boiled water and 72-hours in cold water & $\mathrm{C}$ & 21.1abc & $46.9 \mathrm{ab}$ & $52.8 \mathrm{a}$ \\
\hline 3-minutes in boiled water and 96-hours in cold water & $\mathrm{D}$ & 21.9abc & $55.9 \mathrm{ab}$ & $70.1 \mathrm{a}$ \\
\hline 3 -minutes in boiled water and 120 hours in cold water & $\mathrm{E}$ & 33.0abcd & $50.9 \mathrm{ab}$ & $59.2 \mathrm{a}$ \\
\hline 5-minutes in boiled water and 24 -hours in cold water & $\mathrm{F}$ & $0 \mathrm{a}$ & $49.2 \mathrm{ab}$ & $63.9 \mathrm{a}$ \\
\hline 5 -minutes in boiled water and 48 -hours in cold water & G & 26.1 abcd & $51.1 \mathrm{ab}$ & $63.9 \mathrm{a}$ \\
\hline 5 -minutes in boiled water and 72 -hours in cold water & $\mathrm{H}$ & $12.3 \mathrm{abc}$ & $45.0 \mathrm{ab}$ & $47.2 \mathrm{a}$ \\
\hline 5-minutes in boiled water and 96-hours in cold water & $\mathrm{I}$ & 21.1 abc & 46.9ab & $53.1 \mathrm{a}$ \\
\hline 5 -minutes in boiled water and 120 hours in cold water & $\mathrm{J}$ & 33.0abcd & 61.9ab & $64.6 \mathrm{a}$ \\
\hline Soaking in cold water for 24 hours & $\mathrm{K}$ & $6.1 \mathrm{ab}$ & $43.3 \mathrm{ab}$ & $60.0 \mathrm{a}$ \\
\hline Soaking in cold water for 48 hours & $\mathrm{L}$ & 15.0abc & $40.9 \mathrm{a}$ & $57.0 \mathrm{a}$ \\
\hline Soaking in cold water for 72 hours & M & $12.3 \mathrm{abc}$ & $45.0 \mathrm{ab}$ & $62.0 \mathrm{a}$ \\
\hline Soaking in cold water for 96 hours & $\mathrm{N}$ & 21.1 abc & $48.9 \mathrm{ab}$ & $53.4 \mathrm{a}$ \\
\hline Soaking in cold water for 120 hours & $\mathrm{O}$ & 21.1 abc & $44.7 \mathrm{ab}$ & $55.4 \mathrm{a}$ \\
\hline Soaking in cold water for 144 hours & $\mathrm{P}$ & 19.9abc & $57.0 \mathrm{ab}$ & $66.1 \mathrm{a}$ \\
\hline Keeping in cow dung slurry for 72 hours & Q & $12.3 \mathrm{abc}$ & $51.1 \mathrm{ab}$ & $63.8 \mathrm{a}$ \\
\hline Keeping in cow dung slurry for 96 hours & $\mathrm{R}$ & $12.3 \mathrm{abc}$ & $51.1 \mathrm{ab}$ & $57.8 \mathrm{a}$ \\
\hline Keeping in cow dung slurry for 120 hours & S & $26.1 \mathrm{abcd}$ & $57.0 \mathrm{ab}$ & $67.9 \mathrm{a}$ \\
\hline Keeping in cow dung slurry for 144 hours & $\mathrm{T}$ & $21.1 \mathrm{abc}$ & $45.0 \mathrm{ab}$ & $60.0 \mathrm{a}$ \\
\hline Keeping in cow dung slurry for 168 hours & $\mathrm{U}$ & $6.1 \mathrm{ab}$ & $50.9 \mathrm{ab}$ & $70.1 \mathrm{a}$ \\
\hline 3-minutes in concentrated Hydrochloric acid & $\mathrm{V}$ & 15.0abc & $52.1 \mathrm{ab}$ & $63.9 \mathrm{a}$ \\
\hline 5-minutes in concentrated Hydrochloric acid & $\mathrm{W}$ & 24.1abc & $51.1 \mathrm{ab}$ & $57.0 \mathrm{a}$ \\
\hline 10-minutes in concentrated Hydrochloric acid & $\mathrm{X}$ & 28.1 abcd & $39.1 \mathrm{a}$ & $49.9 \mathrm{a}$ \\
\hline 15-minutes in concentrated Hydrochloric acid & Y & 38.9abcde & $53.2 \mathrm{ab}$ & $70.1 \mathrm{a}$ \\
\hline 30-minutes in concentrated Hydrochloric acid & Z & $32.0 \mathrm{abcd}$ & $53.9 \mathrm{ab}$ & $61.9 \mathrm{a}$ \\
\hline 45-minutes in concentrated Hydrochloric acid & AA & $45.0 \mathrm{~b}$ & $72.8 \mathrm{ab}$ & $83.9 \mathrm{a}$ \\
\hline 60-minutes in concentrated Hydrochloric acid & $\mathrm{AB}$ & $46.9 \mathrm{~b}$ & 76.9ab & $76.9 \mathrm{a}$ \\
\hline 75-minutes in concentrated Hydrochloric acid & $\mathrm{AC}$ & $93.4 \mathrm{~b}$ & $83.9 \mathrm{~b}$ & $83.9 \mathrm{a}$ \\
\hline 90-minutes in concentrated Hydrochloric acid & $\mathrm{AD}$ & $77.7 \mathrm{e}$ & $83.9 \mathrm{~b}$ & $90.0 \mathrm{a}$ \\
\hline
\end{tabular}

\footnotetext{
* Pre-treatments followed by the same letters do not vary significantly.
} 
Annex 2: Cumulative germination percentage of Sapindus mukorossi under various pre-sowing treatments

\begin{tabular}{|c|c|c|c|c|c|c|c|c|c|c|c|c|c|c|c|}
\hline \multirow{3}{*}{ Code } & \multicolumn{15}{|c|}{ Cumulative germination percentage } \\
\hline & \multicolumn{15}{|c|}{ Number of days } \\
\hline & 7 & 14 & 21 & 28 & 35 & 42 & 49 & 56 & 63 & 70 & 77 & 84 & 91 & 98 & 105 \\
\hline A & 0 & 0 & 7 & 20 & 23 & 43 & 47 & 53 & 63 & 73 & 73 & 73 & 77 & 77 & 77 \\
\hline B & 0 & 0 & 3 & 20 & 30 & 50 & 60 & 60 & 60 & 70 & 73 & 73 & 77 & 80 & 87 \\
\hline $\mathrm{C}$ & 0 & 0 & 7 & 13 & 20 & 30 & 33 & 40 & 53 & 57 & 57 & 60 & 63 & 67 & 70 \\
\hline $\mathrm{D}$ & 0 & 0 & 7 & 20 & 27 & 40 & 57 & 60 & 67 & 73 & 80 & 80 & 83 & 83 & 83 \\
\hline $\mathrm{E}$ & 0 & 0 & 17 & 30 & 33 & 33 & 40 & 47 & 60 & 63 & 70 & 70 & 73 & 73 & 77 \\
\hline $\mathrm{F}$ & 0 & 0 & 0 & 0 & 10 & 23 & 33 & 47 & 57 & 67 & 73 & 73 & 73 & 73 & 77 \\
\hline G & 0 & 0 & 0 & 20 & 37 & 40 & 40 & 60 & 60 & 63 & 67 & 70 & 73 & 73 & 77 \\
\hline $\mathrm{H}$ & 0 & 0 & 3 & 7 & 7 & 17 & 33 & 43 & 50 & 50 & 50 & 53 & 53 & 53 & 60 \\
\hline I & 0 & 0 & 3 & 13 & 27 & 30 & 43 & 43 & 53 & 53 & 60 & 60 & 63 & 70 & 80 \\
\hline $\mathrm{J}$ & 0 & 0 & 17 & 30 & 40 & 50 & 67 & 73 & 77 & 77 & 80 & 80 & 80 & 80 & 80 \\
\hline K & 0 & 0 & 0 & 3 & 10 & 20 & 33 & 40 & 47 & 57 & 60 & 60 & 67 & 67 & 73 \\
\hline $\mathrm{L}$ & 0 & 0 & 3 & 10 & 23 & 30 & 30 & 33 & 43 & 50 & 53 & 57 & 70 & 77 & 80 \\
\hline $\mathrm{M}$ & 0 & 0 & 0 & 7 & 13 & 23 & 30 & 47 & 50 & 57 & 67 & 67 & 70 & 70 & 70 \\
\hline $\mathrm{N}$ & 0 & 0 & 3 & 13 & 20 & 27 & 43 & 43 & 57 & 57 & 63 & 63 & 63 & 67 & 70 \\
\hline $\mathrm{O}$ & 0 & 0 & 10 & 13 & 17 & 30 & 40 & 50 & 50 & 53 & 63 & 63 & 67 & 67 & 70 \\
\hline $\mathrm{P}$ & 0 & 0 & 3 & 17 & 37 & 43 & 63 & 67 & 70 & 73 & 77 & 80 & 83 & 83 & 93 \\
\hline Q & 0 & 0 & 3 & 7 & 17 & 27 & 33 & 47 & 60 & 60 & 70 & 70 & 73 & 77 & 87 \\
\hline $\mathrm{R}$ & 0 & 0 & 0 & 7 & 23 & 27 & 47 & 47 & 60 & 63 & 67 & 67 & 70 & 70 & 77 \\
\hline S & 0 & 0 & 13 & 20 & 27 & 37 & 60 & 67 & 70 & 73 & 80 & 80 & 80 & 80 & 83 \\
\hline $\mathrm{T}$ & 0 & 0 & 7 & 13 & 17 & 33 & 40 & 43 & 50 & 60 & 67 & 73 & 73 & 73 & 77 \\
\hline $\mathrm{U}$ & 0 & 0 & 3 & 3 & 7 & 13 & 27 & 40 & 60 & 77 & 83 & 83 & 83 & 83 & 90 \\
\hline V & 0 & 0 & 3 & 10 & 27 & 43 & 43 & 50 & 53 & 63 & 70 & 70 & 73 & 77 & 77 \\
\hline W & 0 & 0 & 23 & 23 & 27 & 37 & 40 & 47 & 60 & 67 & 70 & 70 & 70 & 70 & 73 \\
\hline $\mathrm{X}$ & 0 & 0 & 17 & 23 & 33 & 33 & 40 & 40 & 40 & 47 & 50 & 50 & 57 & 57 & 67 \\
\hline Y & 0 & 0 & 33 & 40 & 43 & 50 & 57 & 60 & 63 & 70 & 73 & 80 & 80 & 80 & 87 \\
\hline Z & 0 & 0 & 23 & 37 & 50 & 50 & 50 & 53 & 63 & 67 & 70 & 70 & 77 & 80 & 83 \\
\hline $\mathrm{AA}$ & 0 & 0 & 30 & 50 & 73 & 87 & 87 & 87 & 87 & 90 & 93 & 93 & 97 & 97 & 97 \\
\hline $\mathrm{AB}$ & 0 & 0 & 30 & 53 & 77 & 80 & 80 & 83 & 87 & 87 & 87 & 87 & 87 & 87 & 87 \\
\hline $\mathrm{AC}$ & 0 & 0 & 63 & 80 & 90 & 93 & 97 & 97 & 97 & 97 & 97 & 97 & 97 & 97 & 97 \\
\hline $\mathrm{AD}$ & 0 & 0 & 90 & 93 & 97 & 97 & 97 & 97 & 97 & 97 & 97 & 97 & 100 & 100 & 100 \\
\hline
\end{tabular}


Annex 3: Number of non-germinated good and rotten seeds with their percentages

\begin{tabular}{|c|c|c|c|c|c|c|}
\hline $\begin{array}{l}\text { Treatment } \\
\text { code }\end{array}$ & $\begin{array}{c}\text { Number of } \\
\text { non- } \\
\text { germinated } \\
\text { good seed }\end{array}$ & $\begin{array}{c}\text { Non- } \\
\text { germinated } \\
\text { good seed } \\
(\%)\end{array}$ & $\begin{array}{c}\text { Number } \\
\text { of rotten } \\
\text { seed }\end{array}$ & $\begin{array}{c}\text { Rotten } \\
\text { seed (\%) }\end{array}$ & $\begin{array}{l}\text { No. of non- } \\
\text { germinated } \\
\text { good and } \\
\text { rotten seed }\end{array}$ & $\begin{array}{l}\text { Non-germinated } \\
\text { good and rotten } \\
\text { seed }(\%)\end{array}$ \\
\hline A & 6 & 20 & 1 & 3 & 7 & 23 \\
\hline B & 3 & 10 & 1 & 3 & 4 & 13 \\
\hline C & 3 & 10 & 6 & 20 & 9 & 30 \\
\hline $\mathrm{D}$ & 2 & 7 & 3 & 10 & 5 & 17 \\
\hline E & 3 & 10 & 4 & 13 & 7 & 23 \\
\hline F & 3 & 10 & 4 & 13 & 7 & 23 \\
\hline $\mathrm{G}$ & 5 & 17 & 2 & 7 & 7 & 23 \\
\hline $\mathrm{H}$ & 8 & 27 & 4 & 13 & 12 & 40 \\
\hline I & 5 & 17 & 1 & 3 & 6 & 20 \\
\hline $\mathrm{J}$ & 4 & 13 & 2 & 7 & 6 & 20 \\
\hline $\mathrm{K}$ & 7 & 23 & 1 & 3 & 8 & 27 \\
\hline $\mathrm{L}$ & 5 & 17 & 1 & 3 & 6 & 20 \\
\hline $\mathrm{M}$ & 6 & 20 & 3 & 10 & 9 & 30 \\
\hline $\mathrm{N}$ & 9 & 30 & 0 & 0 & 9 & 30 \\
\hline $\mathrm{O}$ & 6 & 20 & 3 & 10 & 9 & 30 \\
\hline $\mathrm{P}$ & 2 & 7 & 0 & 0 & 2 & 7 \\
\hline Q & 3 & 10 & 1 & 3 & 4 & 13 \\
\hline $\mathrm{R}$ & 5 & 17 & 2 & 7 & 7 & 23 \\
\hline S & 4 & 13 & 1 & 3 & 5 & 17 \\
\hline $\mathrm{T}$ & 7 & 23 & 0 & 0 & 7 & 23 \\
\hline $\mathrm{U}$ & 3 & 10 & 0 & 0 & 3 & 10 \\
\hline $\mathrm{V}$ & 5 & 17 & 2 & 7 & 7 & 23 \\
\hline W & 4 & 13 & 4 & 13 & 8 & 27 \\
\hline $\mathrm{X}$ & 4 & 13 & 6 & 20 & 10 & 33 \\
\hline Y & 3 & 10 & 1 & 3 & 4 & 13 \\
\hline Z & 3 & 10 & 2 & 7 & 5 & 17 \\
\hline AA & 0 & 0 & 1 & 3 & 1 & 3 \\
\hline $\mathrm{AB}$ & 0 & 0 & 4 & 13 & 4 & 13 \\
\hline $\mathrm{AC}$ & 1 & 3 & 0 & 0 & 1 & 3 \\
\hline $\mathrm{AD}$ & 0 & 0 & 0 & 0 & 0 & 0 \\
\hline
\end{tabular}

